\title{
THE INFORMATION LITERACY MOVEMENT OF THE SCHOOL LIBRARY MEDIA FIELD: A PRELIMINARY SUMMARY OF THE RESEARCH
}

\author{
David V. Loertscher \\ Professor, School of Library and Information Science \\ San Jose State University, San Jose, California, USA \\ DavidL@csn.net \\ Blanche Woolls \\ Director, School of Library and Information Science \\ San Jose State University, San Jose, California, USA \\ Bwoolls@wahoo.sjsu.edu
}

\begin{abstract}
The authors summarize the proceedings of two major conferences, the Treasure Mountain Research Retreat VI and the International Association School Librarianship conference. In addition, the authors look at the entire history of information literacy and bring together the theory development, the research, and practice in school libraries since the late 1980s. Information literacy and critical thinking ideas from the fields of education, cognitive psychology and educational technology have been included.
\end{abstract}

\section{INTRODUCTION}

Two major events happened in 1997 that caused the authors to propose a review of the research on information literacy. The first was the Treasure Mountain Research Retreat VI conference in Portland, Oregon in April and the International Association of School Librarianship conference in Vancouver, British Columbia in July. Both conferences centered on progress in research about information literacy and both had full conference proceedings. The time seemed right for a full review since it had been three full years since Christina Doyle had published her review of information literacy and much research and progress had been made since her publication.

The purpose of this paper is to review the developments, supportive research, and the major documents associated with the information literacy movement as it has developed since the late 1980s. An effort has been made to demonstrate that we as professionals are not alone in this interest but have colleagues with similar ideas across the field of education and from cognitive psychology. The review here should not be construed to mean that the authors support the notion that the constructivist approach is "the only way to teach or learn," since the reality of much educational practice points to a wide variety of successful teaching and learning styles.

This paper is divided into several sections. In the first, a variety of definitions of information literacy are given. This section is followed by a listing of the most prevalent information literacy models that are being used in the field. The assumption has been made that most readers will have ready access to those models and so they are not reproduced here. The models in current use are derivations of important earlier work and so the authors have traced that development for the reader beginning with work done in Great Britain and its importation into the United States and into several other countries.

To show the relationship between what school library media specialists are proposing and other disciplines, related concepts and models have been included - some from persons who specialize in technology, others from cognitive psychologists. Wherever possible, the authors have included the models found or at least abbreviations thereof. 
The last two sections of the paper focus on the research done in teaching information literacy as a process and then monitoring student behavior during the research. These two areas have received the most attention in the past ten years.

At first, the authors were only going to summarize the papers from the Oregon and British Columbia Conferences, However, their interest and research led them much further. Searches of the authors' extensive libraries, plus back issues of School Library Media Quarterly, Emergency Librarian and School Library Media Annual were included. The authors plan a more comprehensive view in the near future.

\section{HISTORICAL ANTECEDENTS OF CRITICAL THINKING AND THE FIELD OF SCHOOL LIBRARIES}

Modern education borrowed rather than created the idea of critical thinking. Its roots are easily traced to the ideas of Plato and Aristotle and onward through Aquinas, Descartes, Bacon, Machiavelli, Hobbes, Locke, Newton, Boyle and many others. The scientific method, a system of knowing, has ruled much of the industrialized world in the 19th and 20th centuries and is considered a foundational element in the advance of society.

In education, the teacher as authority and the student as passive learner has held great weight in the classroom and was encouraged by the behaviorist work of B.F. Skinner. Many of the ideas of instructional development in the world of educational technology stemmed from the behaviorist viewpoint and led to notions that if instruction is carefully designed, anyone can master any concept of knowledge.

A second rival school of thought began with the work of John Dewey in the 1930s and Benjamin Bloom ${ }^{1}$ in 1956. Armed with developments in cognitive and brain research, educators created theories of inquiry or constructivism. This focus challenged teachers in restructured schools to leave their pulpits as sages on the stage to become guides on the side. Numerous reports and research studies have been released demonstrating that constructivist-based education is a major key to academic achievement. An example of such a report is a brief monograph by Newmann and Wehlage entitled: Successful School Restructuring. ${ }^{2}$

In the field of school libraries, the same transformation has taken place. Early interest in the role of the library media specialist in instructional design, popularized first in Canada and then in the United States by Loertscher and Turner was known as 'resource-based teaching.' That movement evolved into increased interest in information literacy (the library media version of constructivism and critical thinking). The term'resource-based learning' was popularized in the late 1980s signifying the adoption of information literacy principles in learning projects using a wide variety of information sources and technologies. Resource based learning is a school library term for inquirybased learning or project-based learning, terms known more widely in the education field.

Meanwhile, library media specialists find themselves in a very interesting mix of philosophies and practices. Some teachers and full faculties have adopted a clear focus of either behaviorism or constructivism. Other schools allow a wide variety of teaching and learning styles to flourish in the same learning environment. Thus, library media specialists must be able to operate comfortably in both camps as they try to bring the best materials and technology into the learning process.

\section{DEFINITIONS OF INFORMATION LITERACY}

A variety of groups and persons defined information literacy in the last ten years. Most concentrate on a series of behaviors that a person possessing this quality might exhibit. In the 1989 American Library Association's statement, ${ }^{3}$ the following description is given:

To be information literate, a person must be able to recognize when information is needed and have the ability to locate, evaluate, and use effectively the information needed... Ultimately information literate people are those who have learned how to learn. They know how to learn because they know how information is organized, how to find information, and how to use information in such a way that others can learn from them. 
In 1992, Doyle ${ }^{4}$ used the Delphi technique to gain consensus among scholars on the following definition:

Information literacy is the ability to access, evaluate and use information from a variety of sources.

By 1997, Holloway, Doyle and Lindsay ${ }^{5}$ added to the above definition by saying that "Information literacy is best thought of as a verb, a way of doing information." Then they translate this notion of a verb into the area of telecommunications:

Information literacy in telecommunications is achieved when learners know when to use on-line resources, how to access information competently, how to evaluate information for accuracy and significance, and how to use this information to communicate effectively. Learners who are able to do this have a life long skills to meet the challenges of the information age. ${ }^{6}$

Woolls ${ }^{7}$ suggests that because information literacy is interwoven with critical thinking and information literacy requires the use of critical thinking skills, the role for the school library media specialist is much greater. She did a summary of various definitions of information literacy from a variety of current fields and found the following from the critical thinking literature:

Critical thinking is the intellectual disciplined process of actively and skillfully conceptualizing, applying, analyzing, synthesizing, and/or evaluating information gathered from, or generated by, observation, experience, reflection. reasoning, or communication, as a guide to belief and action. ${ }^{8}$

King," another critical thinking expert, says "The hallmark of a critical thinker is an inquiring mind." According to Moody, ${ }^{10}$ "There is a distinct difference, however between locating sources of information and locating and interpreting information within sources. She shares Beyer's list ${ }^{11}$ of major critical thinking skills:

Distinguishing between verifiable facts and value claims.

Distinguishing relevant from irrelevant information, claims, or reasons.

Determining the factual accuracy of a statement.

Determining the credibility of a source.

Identifying ambiguous claims or arguments.

Identifying unstated assumptions.

Detecting bias.

Identifying logical fallacies.

Recognizing logical inconsistencies in a line of reasoning.

Determining the strength of an argument or claim.

Quellmalz $^{12}$ approached the subject from the related concept of higher-order thinking:

Students engage in purposeful, extended lines of thought during which they identify the task or problem type, define and clarify essential elements and terms, judge and connect relevant information, and evaluate the adequacy of information and procedures for drawing conclusions and of solving problems.

After looking at all of the various definitions and perspectives, Woolls ${ }^{13}$ proposed that information literacy is a subset of the concept of critical thinking. She pictures the idea that information literacy is something that happens to a learner somewhere between believing and doing: 


\section{Critical Thinking}

\begin{tabular}{|c|l|l|l|l|}
\hline BELIEVE & apply & $\begin{array}{l}\text { decision- } \\
\text { making }\end{array}$ & presentations & questioning \\
\hline reflection & analyze & infer & transfer & meta-cognition \\
\hline scripting & verify & \multicolumn{2}{|c|}{$\begin{array}{c}\text { INFORMATION } \\
\text { LITERACY }\end{array}$} & $\begin{array}{l}\text { sound } \\
\text { evidence }\end{array}$ \\
\hline editing & $\begin{array}{l}\text { problem } \\
\text { solving }\end{array}$ & substantiate & conceptualize & synthesize \\
\hline techniques & challenge & experience & observation & DO \\
\hline
\end{tabular}

\section{Critical Thinking}

Eileen Daniel ${ }^{14}$ looked at the literatures both of the K-12 library arena and the academic library literature and found a striking overlap in the notions of information literacy skills, library and information handling skills, and computer skills. Academic librarians worry through their literature that students are ill-equipped to do simple things such as finding and using periodical articles, understanding the principles of computer searching, and how libraries are organized. They complain that students do not understand a process of investigation from formulating a research question through the production of a product.

Summing up all of the elements of the critical thinking literature, Callison and Tilley ${ }^{15}$ draw the following model illustrating the relationship between all the various definitions and perspectives: 


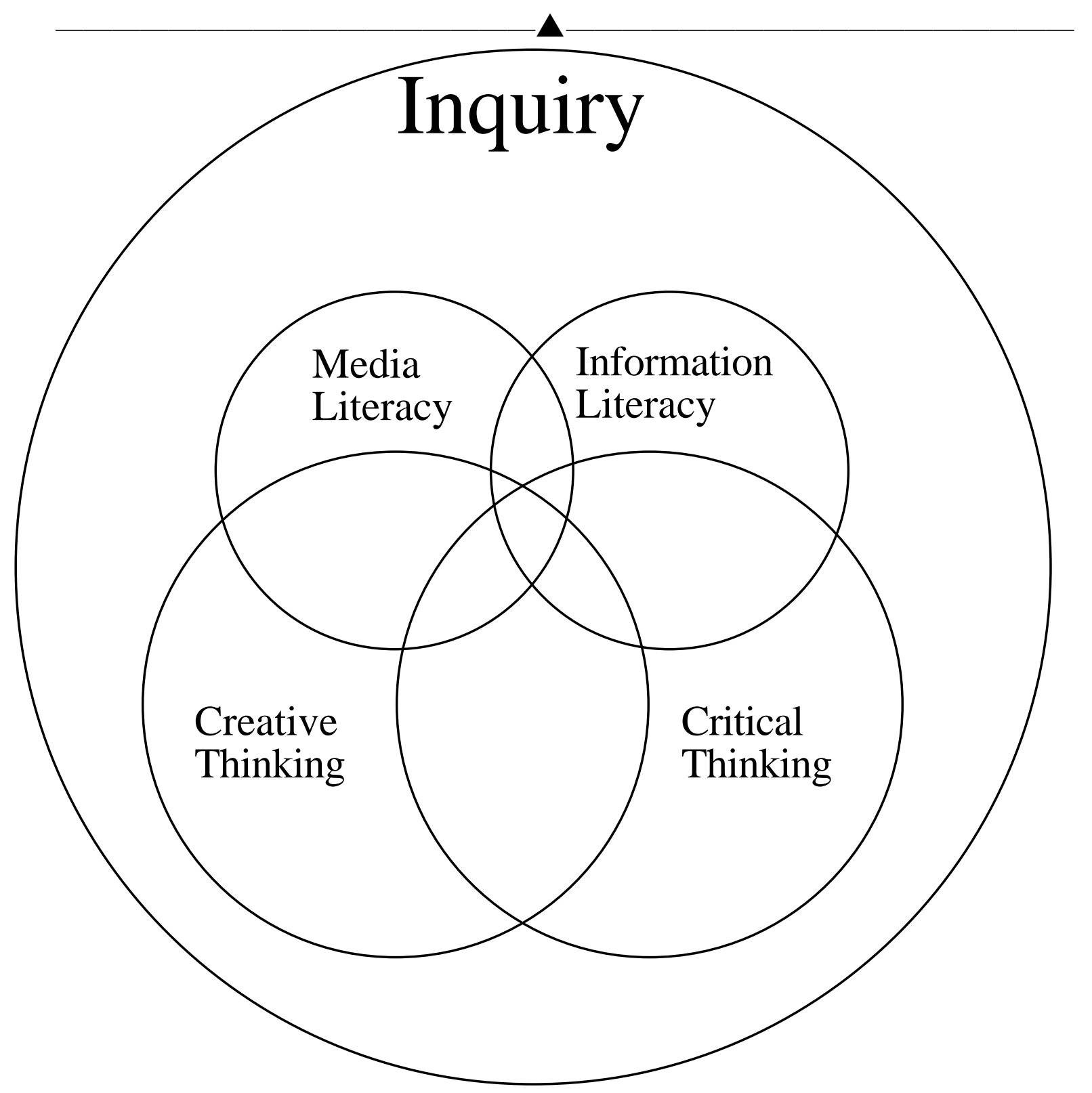

\section{CURRENT MODELS OF INFORMATION LITERACY IN POPULAR USE (BY YEAR OF INTRODUCTION)}

Of the many models that have appeared in the literature in the past 10 years, a few have gained substantial acceptance in the field. The following six models are presented in order of the year they were first published in the school library media literature.

\section{Stripling and Pitts Research Process Model, 1988 ${ }^{16}$}

The Stripling/Pitts model gained wide acceptance upon publication. It guided students through each stage of creating a research paper, but at each stage, the student was asked to reflect upon what had just been done. 


\section{The Kuhlthau Model of the Search Process, 1989 $^{17}$}

In 1989, Kuhlthau published her Search Process Model based upon a major research project done in high schools with students engaged in research. This model not only became popular with the library media profession but by 1997 was used in a number of library schools as a text showing how users face the research process not only as organized or disorganized investigators, but also their confidence level at various stages of their research.

\section{Eisenberg and Berkowitz The Big Six Skills, 1990 ${ }^{18}$}

The Eisenberg/Berkowitz Big Skills model won instant attention because of its simplicity and ease of use by a wide cross section of the field. Since 1990, both creators of the model have done extensive speaking and traveling and have created The Big Six Listserv of persons in the field using the model. It is by far, the most well known model in the field and is being taught widely to students as a guide for their research.

\section{California School Library Association Information Literacy Model, 1994 ${ }^{19}$}

The California model was published in a major guide which not only explained the model, but gave many clear suggestions how to incorporate it into a wide variety of instructional systems and content areas. It was published in a second edition in 1997 and incorporated major suggestions and guidance for teaching information literacy to English learners among others.

\section{Pappas and Tepe Pathways to Knowledge Information Skills Model, 1995 $^{20}$}

Teaming with the Follett Software Company, Pappas and Tepe created an elaborate doublepage rendition of information literacy complete with recommended strategies, forms of expression, and methods of teaching and learning embedded in the model. The model was published in three sizable binders containing numerous full length units of instruction as demonstrations for how to apply the model.

\section{AASL and AECT Information Literacy Standards for Student Learning, 1996 $^{21}$}

As part of the effort to create new standards to replace Information Power, the Vision Committee of the Standards Project published a draft of their thinking to the profession for comment. A revised model in final form is due from the publisher some time in 1998.

\section{ANTECEDENTS OF CURRENT MODELS}

To say that information literacy is new in the school library media field is not exactly true. Going back to the writing of Frances Henne ${ }^{22}$ in the 1960 Standards for School Library Programs, she foresaw librarians integrating library skills instruction into classroom content and said the ultimate goal was the "synthesis of information, the extension of knowledge, the analysis and solution of problems, thinking, reflection, the satisfaction of curiosity, the development of trust, or the derivation of pleasure." The profession at large did not heed the forward-looking words of Henne. Instead, the predominant themes of library skills instruction from the $1960 \mathrm{~s}$ to the 1990s concentrated on the finding and locating of information plus the orientation to the library as a place.

Three reviews of the history of the information literacy movement were found in the literature. Kuhlthau's ${ }^{23}$ was published first in 1987 followed by Doyle, ${ }^{24}$ in 1994 and most recently by Bruce ${ }^{25}$ in 1996. The earliest use of the term "information literacy" is traced to a proposal written in 1974 by Paul Zurkowski ${ }^{26}$ for the National Commission on Libraries and Information Science. This report proposed the achievement of a universal information literacy goal by 1984 . Much excitement had arisen during the 1960s concerning the development of computer information systems and the exponential rise of an information-based society. By 1983, the Nation at Risk report was promoting the concept of a learning society.

Cooke $^{27}$ traces the emergence of information literacy models for librarians to work done in Great Britain and published by Michael Marland in his 1981 book entitled Information Skills in the Secondary Curriculum. The nine steps to research formed the basis of much work done in that country and around the world: 


\section{WHAT DO I NEED TO DO? (formulated and analyze need) \\ 2. WHERE COULD I GO? (identify and appraise likely sources) \\ 3. HOW DO I GET TO THE INFORMATION? (trace and locate individual resources) \\ 4. WHICH RESOURCES SHALL I USE? (examine, select and reject individual resources) \\ 5. HOW SHALL I USE THE RESOURCES? (interrogate resources) \\ 6. WHAT SHOULD I MAKE A RECORD OF? (recording and sorting information) \\ 7. HAVE I GOT THE INFORMATION I NEED? (interpreting, analyzing, synthesizing, evaluating) \\ 8. HOW SHOULD I PRESENT IT? (presenting, communicating) \\ 9. WHAT HAVE I ACHIEVED? (evaluation)}

This early work was part of a project initiated by the British Library Research and Development Department $^{28}$ and resulted in many important publications, particularly the work of Ann Irving ${ }^{29}$ that reached the United States with her consultive work in the Treasure Mountain Research Retreat \# 2.

Hughes and Rankin $^{30}$ had developed a model in 1986 in some work done with the Association for Supervision and Curriculum Development using the following seven steps:

Plan;

Gather information;

Organize information;

Analyze information;

Extend and expand;

Synthesize and create;

Evaluate and apply.

Using the work of Piagé, Taba, and Ehrenberg, Huges also created a developmental structure of thinking skills and process model.

Also in 1986, Eleanor R. Kulleseid ${ }^{31}$ did a summary of research in reading and developmental Psychology with implication for practice. At that time, she was introducing the field to cognitive theories not well known in the library media world and which would become the basis of much of the work of information literacy as a process of inquiry learning.

Mancall, Aaron, and Walker published a major article in 1986 entitled "Educating Students to Think: The Role of the School Library Media Program." ${ }^{32}$ Their concept was of a program that would help students develop thinking skills, pointed to research on how children and adolescents process information and ideas, and gave practical implications for developing information skills in various curricular areas.

Interest in information literacy was, by this time, gaining momentum around the world. This international interest was boosted by the publication of the United Nations' guidelines for the training of teachers in the integration of libraries and information skills into the curriculum by Hall. ${ }^{33}$ She recommended that all teachers be trained in information skills and that the school library concentrate on delivering these skills to students.

In 1987, Carol Kuhlthau ${ }^{34}$ published an extremely important document titled: Information Skills for an Information Society: A review of Research encouraging school library media specialists to carve out the emerging concept of information literacy as a foundational element of their program. That same year, the Washington Library Media Association ${ }^{35}$ published one of the first state guides to information skills. They used a 12-step system to the research process and published a scope and sequence chart for K-12 education listing where each of the skills should be presented and finally mastered.

In 1988, the new national guidelines for school library media programs, Information Power, ${ }^{36}$ declared that the mission of the school library media center is "to ensure that students and staff are 
effective users of ideas and information," and called for the library media specialist to become a key participant in the learning process.

Kathleen Craver $^{37}$ in the Fall of 1989 published a synthesis article summarizing research studies concerning critical thinking and their implication for library work. She urged the field to become interested in this area of research and to know how to improve the ability of students to find, to synthesize, and to apply information in everyday situations. In the same issue of School Library Media Quarterly, Carol Kuhlthau ${ }^{38}$ published her own summary of cognitive research and her information literacy model for the first time in the AASL literature.

One of the most significant documents published in the entire library community was a statement on information literacy published by the American Library Association on January 10, 1989. Known simply as the Final Report, ${ }^{39}$ the document became the basis of much of the discussion about information literacy in both school and academic libraries around the world. After the emergence of this document, Patricia Breivik, the chair of the committee established the National Forum for Information Literacy whose purpose was to popularize the need for information literacy across many organizations and disciplines.

In September of 1989, the first Treasure Mountain Research Retreat ${ }^{40}$ was convened in Park City Utah. Since that time, five other such retreats have occurred. This gathering of school library media researchers and practitioners has provided a great boost to the intelligent discussion of research findings and looking toward the future of this profession. At the 1989 meeting, Kathleen Craver reviewed the research related to critical thinking. Carol Kuhlthau also provided a look into her research on the information search process, Barbara Stein provided a glimpse into the world of cognitive learning styles, and Michael Eisenberg reviewed the research in the area of library and information skills.

In 1993, the Wisconsin Educational Media Association published a major document on information literacy that was adopted and published by AASL as a position paper. ${ }^{41}$ This paper outlined seven basic elements of the research process: defining the need for information; initiating the search strategy; locating the resources; accessing and comprehending the information; interpreting the information; communicating the information; and evaluating the product and process. The following year, the state of Colorado issued their Model Information Literacy Guidelines $^{42}$ which gained national attention.

In 1994, a second major summary of the literature was published by Christina Doyle in her ERIC monograph, Information Literacy in an Information Society: A Concept for the Information Age. $^{43} \quad$ In this document, she reviewed the evolution of the concept of information literacy and demonstrated its relevance in national education goals and curricular concerns.

\section{Elaboration on Information Literacy Models}

Kathy Brock $^{44}$ published an elaboration on other models previously published models that combined a number of factors from mere instructing in the model, to coaching throughout the model, to facilitating a self-directed student.

O'Connell and Henrit ${ }^{45}$ adapted earlier information literacy models from an Australian perspective by showing the core activities of the information process as central flanked by the stages of critical thinking and the basic elements of literacy. Their emphasis is to create a model that has meaning to teachers who are most closely linked to learners. Across the world, Wilson ${ }^{46}$ also worried that teachers should, but do not possess their own mental model of information literacy.

Loertscher ${ }^{47}$ redrew the popular models with the student at the center, emphasizing that what was lacking in many of the models was the need for students to spend a great deal of time consuming the information they find by reading, viewing, and listening. Too many students do not feel they should spend time consuming; they jump over this step IMMDIATELY after information location as they rush toward product creation.

\section{RELATED MODELS AND APPLICATIONS}

Numerous experts from related fields of cognitive psychology, education, and educational technology have been working on the constructivist ideas and putting forth their conceptions of how students can benefit from information literacy-related thinking. While the following models do not exhaust what is currently available in the literature, some major work has been pulled together. 


\section{From Cognitive Psychology}

In a study of cognition and complexity, Reeves ${ }^{48}$ proposed a model by which a student might plan to attack a subject about which the student knows very little. He advocates that teaching a student the model directly could help a student assess whether progress is being made from surface learning to deep learning. The model known as the Reeves Knowledge Management Tool consists of ten steps in three major levels:

FOUNDATIONS

1. Build Background (key dates, events, people, places)

2. Know key words

3. Know key concepts/ideas

RELATIONSHIPS

4. Diagram parts of the topic (classes, categories, objects)

5. Diagram activities that take place in your topic (actions)

6. Diagram the environment of the topic (financial, political, technological, sociological, DEPTH educational, economic, artistic, religious, historical, location)

7. Draw analogies to something you already know (compare, contrast, describe)

8. Visualize (examine/create charts, tables, maps, diagrams)

9. Explain the topic to someone

10. Find themes, patterns, and trends

\section{Information Literacy in the World of Electronic Information}

Mark von Wodtke, an architect in environmental design, published an important book to be used by budding architects and also an article in School Library Media Quarterly concerning the use of high powered information tools in the thinking process. ${ }^{49}$ In putting the mind in the driver's seat over media, von Wodtke posits the following principles:

Mind over Media: People can learn more than which buttons to push. They can learn to work interactively using electronic media.

Navigating: People can learn to navigate in information environments.

Mapping Media Space: People can develop cognitive maps of media space - the information environment they are working in.

Visualization: People can develop models to visualize the realities they are working with.

Creative Thinking: People can learn to use their creative capacity when working electronically.

Collaboration: People can learn and work collaboratively in the emerging electronic information environments.

A Mind Primer: Students can begin to learn creative thinking skills at an early age.

Jamison McKenzie is Director of Technology and Media for the Bellingham Public Schools, Bellingham, Washington and a very well known speaker and author of a provocative web journal. His Research Cycle Model ${ }^{50}$ published in 1996 is an attempt to help student deal with information they find on the Internet. The model is as follows:

- Questioning

- Planning

- Gathering

- Sorting and Sifting

- Synthesizing

- Evaluating

- Reporting

Several authors are beginning to warn about major problems in accessing and using 
Several authors are beginning to warn about major problems in accessing and using electronic information. Fitzgerald ${ }^{51}$ lists numerous problems affecting the quality of information gained from using the Internet. She then lists nine skills needed to effectively evaluation electronic information:

1. Adopt critical consciousness for all Internet interaction.

2. Establish prior knowledge through wide browsing, searching and reading.

3. Distinguish between fact and opinion.

4. Evaluate arguments.

5. Compare and contrast related pieces of information from different sites, sources and search engines.

6 . Evaluate the reliability of online sources.

7. Identify and detect bias.

8. Learn to interpret the conventions of the Internet.

9. Examine assumptions.

\section{Computer Literacy and Information Literacy}

Eisenberg and Johnson took the elements of the Big Six Model and created a checklist for the needed computer skills at each level of model..$^{52}$ For example, for the task definition stage, learners should be able to use e-mail, desktop conferencing and idea generating software to help define an information problem. Their checklist covers a full spectrum of technical skills and any learner mastering the list would be considered a technology expert.

Penrod and Douglas ${ }^{53}$ define information technology literacy as the ability to:

- operate and communicate with technological devices;

- understand how subsystems fit together to form systems or networks;

- understand documentation and how to utilize applications software;

- understand the basic jargon or terminology of information technology;

- solve problems through the use of technology;

- identify and use alternate sources of information;

discuss the history and future of information technology; and

- have some insight into the ethical and human impact issues of information technology.

\section{Media Literacy}

A cousin to information literacy is media literacy that seeks to build critical thinking as young people interact with the mass media. Several important publications have circulated widely in the library media field including David Considine and Gail Haley's book Visual Messages. ${ }^{54}$ This publication not only outlined the content of visual literacy but gave suggestions in a wide variety of curricular areas for incorporating critical thinking exercises.

A second publication, Media Alert!: 200 Activities to Create Media-Savvy Kids by Sue Summers $^{55}$ was published in 1997. Fifty different concepts of media literacy are presented with suggested activities for each by age and grade level. Its stated purpose was to guard against young people who are sponges (believing everything they read, view, or hear), or cynics (believing nothing they read, view, or hear), but who are healthy skeptics, equipped with sound judgmental skills.

Pappas and Tepe, ${ }^{56}$ in their Treasure Mountain VI paper, urge library media specialists to go beyond the current research process models to embrace media/visual literacy and technology literacy under the same umbrella - to recognize, that students must and do take their information not only from print, but from what they see, hear, and experience and that much of that information is now coming electronically through various technological devices which demand navigational facility.

\section{Critical Thinking}

One of the most important theorists of the critical thinking field is Robert H. Ennis. ${ }^{57}$ His critical thinking model is oft quoted in the educational literature and looks at critical thinkers from two perspectives, the disposition of the thinker and the ability of the thinker. Ennis lists 12 abilities of the thinker:

1. Focusing on a question

2. Analyzing arguments 
3. Asking and answering questions of clarification and/or challenge.

4. Judging the credibility of a source.

5. Observing and judging observation reports.

6 . Deducing and judging deductions.

7. Inducing and judging inductions.

8. Making value judgments.

9. Defining terms and judging definitions in three dimensions.

10. Identifying assumptions.

11 . Deciding on an action.

12. Interacting with others.

One of the popular centers for critical thinking is the California State University at Sonoma. Located in the famous Napa valley, the Center for Critical Thinking conducts critical thinking seminars each summer. They publish a web page where they list their "35 Dimensions of Critical Thought."

\section{Skills Needed for the Workplace}

The SCANS Report, $1992^{59}$ provided the library media community with a great deal of evidence that the information literacy skills are needed to function in the workplace as well as in elementary, secondary, and higher education. SCANS stands for The Secretary's Commission on Achieving Necessary Skills and was published by the U.S. Department of Labor. The competencies were as follows:

\section{SCANS WORKPLACE COMPETENCIES}

\section{Managing Resources:}
a. Manage time
b. Manage money
c. Manage materials
d. Manage space
e. Manage staff

2. Exhibiting Interpersonal Skills:

a. Work on teams

b. Teach others

c. Serve customers

d. Lead work teams

e. Negotiate with others

f. Work with different cultures

3. Working with Information:
a. Acquire/evaluate data
b. Organize/maintain information
c. Interpret/communicate data
d. Process information with computers

\section{Applying Systems Knowledge}

a. Work within social systems

b. Work within technological systems

c. Work within organizational systems

d. Monitor/correct system performance

e. Design/improve systems

\section{SCANS FOUNDATIONS}

\section{Demonstrating Basic Skills}
a. Reading
b. Writing
c. Arithmetic/Mathematics
d. Speaking
e. Listening

\section{Demonstrating Thinking Skills}

a. Creative thinking

b. Decision making

c. Problem solving

d. Thinking logically

e. Seeing with the mind's eye

8. Exhibiting Personal Qualities
a. Individual responsibility
b. Self-esteem
c. Sociability
d. Self-management
e. Integrity

\section{Helps for Parents}

Eisenberg and Berkowitz created a book that translates the Big Six Model into a process parents can use to help children learn while doing school-related homework and assignments. Titled 
Helping with Homework: A Parent's Guide to Information Problem-Solving, ${ }^{60}$ the book explains the Big Six and the Super Three stages in information problem solving, explains how technology can help in finding and using information, and gives tips for assisting with assignments in a wide variety of common homework subjects.

\section{Habits of Mind}

Loren J. Thompson, in his book, Habits of the Mind ${ }^{61}$ (popular in the Coalition of Essential Schools group) presents the idea that all content teaching should have as its core the teaching of reasoning skills. Much of what he includes is the teaching of logic systems and the building of knowledge using strict rules of evidence. Each learner, he says, should be a problem solver who has the following five characteristics:

1. A positive attitude.

2. A concern for accuracy.

3. The ability to break the problem into smaller parts.

4. Restraint to avoid guessing.

5. A willingness to be active in the problem solving process.

Thompson supports the use by students of a systematic strategy which he says will not always produce right answers, but it will generate the right questions that will lead to appropriate solutions. These questions will include:

- Can the problem be defined?

- What do we want to achieve?

- What do we know about the problem?

- What don't we know that may be important?

-What assumptions can we make?

\section{I-Search Process}

Macrorie $^{62}$ in his book The I-Search Paper created a very popular method now widely adopted by college and high school English teachers for a student to systematically navigate the research process to create a research paper. The system is very similar to the research process models in the library media field and any teacher using the Macrorie model would instantly recognize the similarities. Nowhere in Marcrorie's book does he list his model in 1,2,3 order in its entirety, but the following is the sense of his method:

1. Let a topic choose you.

2. Search for information

- find experts or authorities and listen carefully and note useful ideas

- know a lot about your topic before you interview people

- ask for advice on the very best information sources

3 . Test the information from both experts and other sources.

4. Write the paper

- What I knew and did not know about the topic before I started.

- Why I'm writing this paper.

- The search (story of the hunt).

- What I learned or did not learn.

\section{Edit the paper}

\section{Curricular Models}

The process of inquiry is being promoted in many curricular areas in national standards created during the federal initiative to reform curriculum in the early 1990s. Mary Dalbotten from the State Department of Education in Minnesota did an extensive analysis of the various national standards documents, extracting information literacy components and then comparing them to the Inquiry 
Process of Minnesota's Graduation Standards. ${ }^{63}$ Her comparison included the following disciplines:

Arts - Dance, Music, Theatre, and Visual Arts ${ }^{64}$

Civics \& Government ${ }^{65}$

English/Language Arts $^{66}$

Foreign Language $^{67}$

Geography ${ }^{68}$

Health ${ }^{69}$

\author{
History $^{70}$ \\ Mathematics $^{71}$ \\ Physical Education ${ }^{72}$ \\ Science $^{73}$ \\ Social Studies ${ }^{74}$ \\ Technology Education ${ }^{75}$
}

In virtually all of the standards documents, Dalbotten could find parallel process skills of generating questions, determining feasibility, collecting data, reducing and organizing data, displaying data, and compiling conclusions.

\title{
TEACHING INFORMATION LITERACY AS A PROCESS
}

Application of information literacy models as a replacement for the teaching of traditional library skills is beginning to make inroads among school library media specialists. Once models are internalized in the thinking of the library media specialist, the practical problem is how to apply these models and create intervention strategies into teaching and learning. Numerous techniques have been suggested including direct teaching of the models to children and young people and "just in time" instruction that focuses the teaching in the form of mini-lessons at the time students need a particular information strategy. In this section of the paper, a review of a few of the interventions are presented with the knowledge that there is a great deal of developmental work to be done in translating theory into practical ideas.

\section{Methods of Integrating Information Skills into Instruction}

VanDeusen and Tallman $^{76}$ examined the relationship between scheduling students into the library media center and how information skills instruction was performed. They found that in the elementary school when library media specialists used a mixture of flexible schedule and fixed schedule, that information skills were integrated more often, particularly when the principal's expectation of integrated skills was high.

$\mathrm{Kuhlthau}^{77}$ in a case study report, made the following comments: "This study indicates that successful implementation of the process approach to information skills calls for a shared philosophy of learning. It requires development of an instructional team and a break with the traditional concept of one teacher to one classroom. It requires a commitment to developing skills for living, working, and participating in changing technological society. It demands highly competent educators who instruct, guide, coach, and assess students and who design and redesign programs to enhance the learning process."

\section{Teaching the Big Six}

Much of the success is due to the popularization of The Big Six Skills of Eisenberg and Berkowitz. Both authors do extensive speaking engagements, and have published books, ${ }^{78}$ videos, ${ }^{79}$ and have a listserv. ${ }^{80}$

\section{Major Manuals of Theory and Practice}

Two major publications gained acceptance with their practical approach to the teaching of information literacy. The first was Stripling and Pitts' Brainstorms and Blueprints ${ }^{81}$ and the second was From Library Skills to Information Literacy: A Handbook to the 21st Century ${ }^{82}$ first published in 1994 and now in its second edition (1997).

An earlier publication served to introduce many in the profession to information literacy. Carol Kuhlthau, chair of the Information Skills Task Force for AASL in 1990-91 published a collection of original pieces on information literacy in an issue of School Library Media Quarterly and then as a separate publication entitled Information Literacy: Learning How to Learn. ${ }^{83}$ 


\section{Teaching Text Structure}

Because students do much of their reading of content in expository text, teachers of reading have been concerned that even when a reader might read fiction smoothly and with comprehension, that skill does not often translate to expository text. A great deal of professional literature is aimed at "reading in the content areas" and covers such skills as: indexes, etc.)

a. using format features and organizational aids (title pages, tables of contents,

b. using internal text structure (headings and subheadings, lists, text boxes, graphs,

tables, marginal notes)

c. skimming and scanning techniques

d. identifying the main idea

e. outlining and notetaking

f. being a critical reader ${ }^{84}$

Fostering Habits of Mind and the Inquiry Process

Stripling, ${ }^{85}$ in a major article, reminded the profession that the entire framework of information literacy is connected to the constructivist notion of learning theory. Creating a Thoughtful Learning Cycle model, Stripling shows the relationship between the personal understandings of a students and the inquiry process, the content information, and the assessment of that understanding. She notes that prior learning affects new learning, that learning involves both content and process, that learning is social, and that learning is deeper when supported by a learning framework.

The framework Stripling ${ }^{86}$ discusses is very much alive in the educational restructuring movement. The Coalition of Essential Schools, one of the major players in reform, encourages teachers to focus students on the process during any type of inquiry activity with questions such as:

a. How do you know what you know? What's the evidence: Is it credible?

b. What viewpoint are you hearing, seeing, reading? Who is the author? Where is she/he standing? What are his/her intentions?

c. How are things connected to each other? How does "it" fit in? Where have you heard or seen this before?

d. What if...? Supposing that...? Can you imagine alternatives?

e. What difference does it make? Who cares?

Tastad and Collins ${ }^{87}$ in their observation of a middle school writing center feel that students will not attempt to build habits of mind and see information query as a process unless the teacher is using a constructivist approach to learning. They feel that a teacher using a lecture method of instruction is very unlikely to encourage any process concepts in their pupil's behavior. In their research study, when a writing center was set up to encourage personal inquiry methods, it immediately conflicted with the teaching strategies of any teacher using the behaviorist model.

\section{MONITORING STUDENT BEHAVIOR DURING THE RESEARCH PROCESS}

Carol Kuhlthau urged library media specialists to monitor student behavior during the information sleeking process to maximize the contribution and supportive nature of the human interface in the entire process. Indeed, Kuhlthau discovered that feelings of confidence are somewhat akin to riding a roller coaster during an information quest. Numerous other studies are beginning to probe student behavior to look for clues about successes and failures, attitudes and feelings.

\section{Imposed Questions vs. Their Own Questions}

Not surprisingly, Melssa Gross ${ }^{88}$ seeking to provide some baseline data found that as children enter school and begin to interact with the information bank in the school library, they do so in Kindergarten and first grade from a basis of curiosity about their own questions and interest, but by the time they are in 6th grade, questions imposed by adults dominate their information seeking motivation. 


\section{Background Knowledge and Information Skills}

In a study of eleventh and twelfth grade science students on a library assignment, Pitts ${ }^{89}$ studied student's information seeking behavior. While concluding that the students learned very little and received little guidance during their library assignment, Pitts created the following equations relating mental models to information skills:

1. Novice subject understandings + expert information skills $=$ students who may use information skills to find information necessary to strengthen subject knowledge.

2. Expert subject understandings + novice information skills $=$ students who may articulate information needs clearly to those who can help.

3. Novice subject understandings + novice information skills $=$ students who are not likely to make progress on either strand.

Pitts noted that "students were not overwhelmed by too much information. Instead, they were floating in a sea of information but did not know how to access more than a few useful drops." ${ }_{90}$

\section{Searching Skills}

There has been considerable study of student searching behavior, particularly with online catalogs. After reviewing numerous studies, Nahl and Harada ${ }^{91}$ did their own study with secondary students in six schools. They tested the ability of students to interpret and construct search statements in a presearch activity. They measured both accuracy of search statement and took a self-confidence measure. Students achieved scores averaging 60 percent correct and those who reported high confidence had significantly higher scores. They also noted that adequate content knowledge in the subject area was a crucial skill in coming to the index. They recommended a variety of approaches to teach the complexity of searching and warned against the idea that "one shot" instruction was sufficient.

As catalogs evolve from print to electronic, Walter, Borman, and Hirsh ${ }^{92}$ examined children's searching skills as they queried The Science Library Catalog (a catalog designed with a search engine specifically for children). They found that children are able to use both browsing modes and keyword systems in automated library catalogs. If the topic was simple and straightforward, the children had success, but complexity, spelling, and vocabulary problems create barriers. They also noted that age, gender, and computer experience had minimal effect on children's ability to use the catalog, but that age might be a factor in keyword systems.

Numerous other studies of children's behavior and strategies of using automated catalogs are starting to appear. Paul Solomon ${ }^{93}$ notes the high rate of search failure among children because most software interfaces in automated catalogs seem to be designed according to a "one-size-fits-all" mode, and that size does not fit children particularly well. Other studies probing the same topic were listed and reviewed briefly in the "Current Research" column of which the Solomon research report was a part.

\section{Evaluating Information}

Kafai and Bates ${ }^{94}$ used a hook to engage elementary school students in searching for information connected to the curriculum on the Internet. Under the guise that students were preparing search guides for other students, students under the tutelage of graduate students in the UCLA library school learned to surf the web. One of the major findings was that younger students (fourth grade and below) are capable of locating information on the web but are uncritical of the content they find. This finding demonstrates a connection between critical thinking and mental maturity. Children also prefer web sites with high visual contents and short, simple textual content. They prefer more animation and interactivity and have little patience for long download times. While the students enjoyed the finding of the information, particularly if they found something like a picture of a human leg chewed by a shark, they were reluctant to write annotations for the sites they discovered.

\section{Copying During the Research Process}

McGregor and Streitenberger ${ }^{95}$ have conducted several studies watching students as they extract information from various sources and then transcribe that information into their finished project. They find that when students receive very little guidance, they tend to copy a great deal from 
original sources rather than paraphrase or synthesize the ideas they find. When the teacher reminds students not to plagiarize, the researchers found that students copied less but it was still present in their final products. Teaching students how to extract information and do it ethically is still a challenge and another problem is to help teachers and students frame inquiry so that synthesis rather than regurgitation of ideas is the central focus of the quest.

\section{Attitudes and Motivation}

Carol Kuhlthau studied the attitudes and feelings of confidence throughout the research process. Students exhibited a wide variety of feelings from poor to strong self-confidence. The variations in attitude were included as a part of her model cited earlier in this paper.

Havener and Latrobe, ${ }^{96}$ in their Treasure Mountain VI paper, reported investigating students engaged in research and related their experiences to a variety of psychosocial theories including alienation theory, gratification theory, knowledge gap theory, resilience theory, dynamic social impact theory, and social cognitive theory. They found elements from all six theories operational during students' experiences as students struggle to develop self-regulatory skills in the learning process. They encouraged library media specialists to recognize these struggles and extend assistance and encouragement throughout the process.

Small $^{97}$ is concerned that little attention is being paid to motivational issues in the information literacy effort even when a widely accepted goal of education is to develop intrinsically motivated, life-long learners who want to learn and actually enjoy the learning experience. After exploring numerous motivational theories, Small gave numerous suggestions for increasing motivation during the research process but noted that she had just begun to identify the best strategies for elevating motivation.

\section{Applications to Specific Groups of Students}

More and more research is being aimed at probing how various students react when information literacy models are applied in specific situations with a specific group of learners. Examples include:

\section{Low Achieving Students}

Linda Friel ${ }^{98}$ finds that the Kuhlthau model can be very successful with low achieving freshman if the library media specialist conducts a "warmth seminar" and provides constant nurturing and encouragement throughout the research experience.

\section{Gifted Students}

McGregor ${ }^{99}$ studied a group of gifted high school students in Canada in 1993 who were completing a library research assignment. She was not impressed with these students process approach to their information problem. She said: "Students do not instinctively operate in a metacognitive manner." Instead, they operated intuitively without awareness of process but they did seem to operate at all levels of Bloom's Taxonomy on their rush to create an assigned product.

\section{High School Students in General}

In a 1992-93 study of high school students doing research assignments in the Holt High School Library in Lansing, Michigan, Garland ${ }^{100}$ found that student satisfaction during the research process supported the earlier Kuhlthau research findings. Elements related to satisfaction with the research process included student choice of topic within the confines of the subject matter; group work; topics clearly related to course content; clear communication by teachers of goals and the means of evaluation; and attention to intermediate steps as well as to the final product.

\section{Students Studying Specific Topics}

Todd $^{101}$ studied how a group of teenage girls processed several rounds of information concerning drugs. He found that in-depth work by librarians and teachers to understand how cognitive change happens, giving students a chance to evaluate the process of learning, and provision of a wide variety of information sources could well mean a greater quality of life for adolescents coping with realistic questions. 


\section{Bilingual Students}

Walster $^{102}$ reminded the Treasure Mountain VI audience that bilingual students present a great challenge not only to teachers but also to library media specialists as these students encounter the information society. Walster asked numerous questions as she studied middle school students engaged in quests for information:

- How can we assure that non-English speaking and reading students will have the same access to information skills training and practice as other students?

- How can we develop appropriate strategies and techniques for working with bilingual and monolingual students when we have limited bilingual or English as a Second Language training?

- How will we as a profession address the real and substantive problems associated with evaluating/assessing the information literacy skills of bilingual or monolingual students?

After her observations, Walster had a number of recommendations for the library media specialist, a few of which are given here:

- work closely with bilingual teachers in the school

- have materials in appropriate languages and appropriate dialects of common languages

- recognize cultural and social meanings associated with the entire learning process

- be aware of the hidden language demands made on English learners throughout the entire information seeking process and make compensation for them.

Recognizing the extensive needs of the English learner in California schools, the California School Library Association revised its From Library Skills to Information Literacy manual mentioned earlier in this paper into a new second edition that integrates concerns, strategies, and advice for adults working with English learners during the research process. Interested readers are referred to that publication as the most extensive coverage of the problem yet to appear in the literature.

\section{Academic achievement and information literacy}

Todd, ${ }^{103}$ in a study of 14-year-old low achievers doing a science investigation in Australia, found that integrated information skills instruction appeared to have a significant positive impact on students' mastery of prescribed science content and on their ability to use a range of information skills to solve particular information problems.

\section{Assessment of student learning}

The subject of assessment of learning is a broader topic than information skills but library media specialists are anxious to know the effects of their interventions on student learning. In 1994, Carol Kuhlthau published a collection of articles dealing entitled Assessment and the School Library Media Center. ${ }^{104}$ Several of the articles in that collection deserve mention.

Madaus and $\operatorname{Tan}^{105}$ and Neuman ${ }^{106}$ review the history of the assessment movement in the educational field and the conflict between the behavioralist and constructivist camps to discover what a student knows when an inquiry method is used. They want to know how to test more than surface learning of factual or computational knowledge.

Jackson $^{107}$ looked at popular national tests such as the Iowa Test of Educational Development to ascertain whether information skills were being tested. She found that none of the tests attempted to assess the process of narrowing or broadening a topic, computerized information retrieval skills, development of a thesis, development of a search strategy, or ordering the steps in a search strategy. She concluded that other means of assessment such as portfolio compilations, oral recitations, and professional judgment would be more appropriate for measuring student success in the research process.

Numerous other authors in the Kuhlthau collection introduced school library media specialists to the movement of authentic assessment utilizing such techniques as portfolios, 
performances, the diagnostic interview, the questionnaire, observation, personal contact, and reflection tools such as learning logs, progress logs, and process logs.

\section{Assessment of student performance using a rubric}

Two major assessment tools of student performance done in the form of rubrics have appeared in the literature. The first was created in Colorado by the Colorado State Library and the Colorado Educational Media Association in 1996. It was published nationally for the first time in: From Library Skills to Information Literacy. ${ }^{108}$ This instrument judges any student linformation-based product using five target indicators:

1. The student as a knowledge seeker;

2. The student as a quality producer;

3. The student as a self-directed learner;

4. The student as a group contributor; and,

5. The student as a responsible information user.

The rubric is formed using these indicators in four levels of attainment: In progress, Essential, Proficient, and Advanced.

The second major assessment tool was published in 1997 by the Kansas Association of School Librarians Research Committee ${ }^{109}$ using an AASL research grant. This rubric rates student information products in five areas:

1. Articulates a clear, complete understanding of assignment/problem.

2. Demonstrates understanding of most of assignment/problem.

3. Shows vague, unfocused understanding of assignment/problem.

4. Is aware of assignment/problem.

NA Not applicable/nothing available

Each of the factors is rated on a five point scale as follows:

NA - Not applicable or no evidence is available

1 - Awareness

2 - Understanding

3 - Demonstration

4 - Application

Ennis and Norton ${ }^{110}$ propose something close to a rubric evaluation in their list of possible checkpoints at three levels:

\section{Clarity}

(Focusing on a question)

Student is able to identify a problem.

Student is able to propose an hypothesis.

Student is able to judge if the hypothesis is acceptable.

(Analyzing arguments) Note: This may have some overlap with the above.

Student finds a variety of statements to answer the question.

Student finds a variety of statements to support the hypothesis.

Student finds a variety of statements identifying arguments that are not explicitly stated.

Student is able to determine relevance of statements.

(Asking appropriate, clarifying questions)

Student is able to analyze the amount of information found.

Student is able to determine if enough information has been located to prepare the report.

Advance Clarity

Student has sufficient background knowledge to continue.

\section{(Defining terms)}

Student understands where to locate definitions.

Student can determine the "best" definition from those in source.

Student can expand the existing definition with examples. 
(Identifying assumptions)

Student can point out assumptions an author has stated.

Student can state assumptions that author has made but not stated.

Basis

Student can describe assumptions that author might have used.

(Judging credibility)

Students check credibility of content, only.

Students check credibility of content and sources.

(Observation)

Students check credibility of assumptions made from stated facts in content.

Student is able to take credible notes.

Student is able to observe information sources and incorporate new findings into report.

Student is able to transfer observations from previous experience or to transfer

Inference

learning to other areas of the curriculum.

(Deducing and judging deductions)

Student is able to judge cause and effect.

Student is able to analyze whether necessary conditions are satisfied.

Student is able to interpret double negatives in sentences.

(Inducing or inductive influence)

Student is able to generalize and infer to hypotheses that are supposed to explain the facts. Does smoking cause cancer?

(Making value judgments)

No plausible alternatives

Interaction

Deciding on an action.

Interacting with others in discussions, presentations, debates, and written pieces:

Student participates in discussion.

Student leads discussion.

Student plans discussion.

Employing Fallacy Labels

Student detects errors in statements of fact.

Student detects errors in assumptions and hypotheses.

Student revises assumptions and hypotheses.

Interdependence

\section{Other Assessment Techniques}

Library media specialists and teachers might be impressed that during the learning process, students exhibit enthusiasm, excitement, well behaved attention, answer questions, and are busy. According to Resnick, ${ }^{11}$ these characteristics do not necessarily guarantee that effective thinking is occurring but the following signposts have additional evidence of critical thinking:

- The path of action is not fully specified in advance.

- The total path is not 'visible' from any single vantage point.

- Multiple solutions with costs and benefits are provided rather than unique solutions.

- Nuanced judgment and interpretations are involved.

- Application of multiple criteria is in evidence, some in conflict with one another.

- Not everything bearing on the task at hand is know.

- Students must self-regulate the thinking process rather than allow another to set the

steps for the solution.

- Students find meaning out of apparent disorder.

- Higher order thinking requires considerable mental work.

Woolls ${ }^{12}$ in her Treasure Mountain VI paper reviews a wide variety of other assessment techniques including:

- Commercial tests covering some aspects of critical thinking. 
- Creating your own tests using good testing practices.

- Using multiple choice tests that have been constructed specifically to measure critical thinking.

- Use self-assessment so that students start comparing their own work against a framework of good research practices.

- Use performance/presentation measures.

- Have students use checklists as they prepare their products.

- Do interviews.

- Have students use writing to evaluate their thinking.

- Evaluate the quality of the resources students choose to collect their information.

- Do a portfolio assessment.

- Do direct observation of the learning process.

- Teach and then observe student's questioning techniques.

- Evaluate the ability to formulate a search strategy.

- Evaluate the evaluation itself.

Other valuable contributions to the creation of assessment criteria and measurements include the work of Paul and Nosich, ${ }^{113}$ Brookfield, ${ }^{114}$ Baron, ${ }^{115}$ and Halpren. ${ }^{116}$

\section{CONCLUSIONS}

Over the past 20 years, the theorists of the school library media community have been carving out the role of the library media specialist in relation to the learning activities of the school. They have not been satisfied with the support and supply role where the professional builds a functioning warehouse or network central information infrastructure. Instead, they have requested the professional library media specialist do outreach into essentially four major areas:

Basic literacy (reading)

Collaboration (resource-based teaching and resource-based learning)

Information literacy

Enhancing Learning Through Technology

The pressure of the warehousing tasks in the typical school library media center plus the lack of clerical and technical help has put a tremendous guilt-ridden role model upon individuals who are already overworked. Yet, the theorists have noted that in so many parts of the world, professionals are being replaced by cheaper non-professional staff when the contribution of the library media program is not perceived as essential or when financial exigency occurs even when the role is valued.

As technology continues to come into the classrooms of the world and connections to the Internet are established, the pressure of making the teacher solely responsible for good learning continues. Above and beyond the necessity for creating the information infrastructure and keeping it in working order, many do not feel that the typical school can afford an information professional. Neither do they feel that there are sufficiently trained people to assist in the proposed human interface role even if they could afford such a person.

Yet other major thinkers such as Ted Sizer, leader of the Coalition of Essential School Movement, realize that for schools using the inquiry method, school libraries are the foundational elements of the constructivist philosophy and that fully prepared library media specialists are key personnel of a successful program to restructure education.

The library media program in a school can make a difference in the learning process but how an individual library media specialist chooses to do so is a major challenge. Of the four principal program thrusts listed above, the most excitement in the literature of the past ten years has been information literacy.

This paper has reviewed what is known from an incomplete search of the literature, but has included the major sources well known in the school library media field and has looked outside the field for significant literature and research currently being touted as significant in the educational literature.

What have the authors learned in this investigation? The following principles seem to make sense at this point in time: 
1. The information literacy models, while evolving slightly over the past ten years, are keeping up with the advance of research in cognitive development and solid principles of inquiry.

The early work of Kuhlthau, Eisenberg, and now the AASL standards for student learning are in solid agreement with efforts in education to make the learning process concentrate on what students know and be able to do, particularly when the method used by the teacher is inquiry.

2. There is much to be learned in the educational community concerning information literacy simply because so many segments of the community are working on the same problem.

We are not alone as a professional group in promoting better use of information and information technology. Numerous models, strategies, and assessment tools from a wide variety of sources are helping teachers and library media specialists plan interventions that will have an impact on learning. The opportunity to collaborate is easier when teachers are seeing the same messages in their literature as library media specialists are encouraging.

3. In spite of the interest in constructivist learning and inquiry, behaviorist approaches in education are still very strong.

Numerous authors have mentioned the need for a teacher to use the inquiry model if the research process as defined by library media specialists is to be successful. The reality is that there are a wide variety of teaching styles being used and the inquiry method is not currently the most popular model. Library media specialists need to be realistic about their intervention strategies and should be able to work within a wide range of teaching and learning styles to achieve their goals in implementing information literacy and enhancing learning through technology.

4. A great deal of research is being done observing students as they engage in research that requires a wide variety of information sources using a wide variety of information technologies.

To date, the research shows that we are not making great strides teaching students or teachers to handle new oceans of information currently available to most students. The way teachers design or encourage investigations, the expectations of students they set, the ways students understand what is expected of them, and the process by which students are performing investigations are a long way from what the literature is envisioning should happen. Major manuals of good practices and sound strategies are appearing in the literature and tools such as the Big Six Listserv are helping library media specialists translate the theory into practice. The question is whether practice can be affected fast enough to produce the desired impact and to carve out an essential role for the library media specialist in a school.

5. Methods to assess whether students are learning more effectively using information literacy principles are still in their infancy.

The press of continued reliance on testing surface learning and factual knowledge within each discipline is not only alive and well but receives continued emphasis by proposals for nationwide testing instruments which will perceive how well students are doing in comparison to students in a wide variety of world nations.

Some bright spots in ares of authentic assessment include the use of portfolios, performances, and other product evaluations. Library media specialists should have a wide variety of such methods in mind as they collaborate with teachers to create information-based projects involving the library media center and information technology.

6. Library media specialists responding exclusively to the current interest in information literacy do so at their own peril.

Library media specialists are like any other other educators who are looking for what is new and exciting. They want to develop initiatives to promote the new wave of fashionable ideas. The authors believe that a more balanced approach to library media programming is not only desirable but wise. Politically astute library media specialists realize they need to be in a leadership position as new information technologies arise, and as new methods of curricular emphases and programs emerge. Yet the need to make an impact in all of the areas remains: 
- creating capable and avid readers,

- collaborating with teachers and students in creating effective learning experiences,

- enhancing and teaching information literacy, and

- ensuring that technology enhances the learning process.

Information literacy is an attractive element of library media programs because it is part of the tradition of a democratic society. Many philosophers have dreamed of nations and a world order based on critical thinkers with the freedom to challenge the prevailing ideas coupled with the problem solving skills to attack major problems of society. At the same time, we also recognize that the notion that all students should be critical thinkers is not universally accepted. Parents, religious leaders, governmental leaders, business leaders, ideologists and even teachers are willing to tolerate critical thinking as long as it does not challenge their own sphere of control. We might be spoilers, revolutionaries, or just plain troublemakers in our quest for critical learners. It's worth it. 
${ }^{1}$ Bloom, Benjamin. Taxonomy of Educational Objectives: The Classification of Educational Goals. New York: Longmans, Green, 1956.

${ }^{2}$ Newmann, Fred M. and Gary G. Wehlage. Successful School Restructuring: A Report to the Public and Educators by the Center on Organization and Restructuring of Schools. Madison, WI: Center on Organization and Restructuring of Schools, 1995. (available from the American Federation of Teachers, The Association for Supervision and Curriculum Development, National Association of Elementary School Principals, or The National Association of Secondary School Principals)

${ }^{3}$ American Library Association. Presidential Committee on Information Literacy. Final Report. Chicago: ALA, 1989, p. 1.

${ }^{4}$ Doyle, Christina S. Information Literacy in an Information Society: A Concept for the Information Age. Syracuse University: ERIC Clearinghouse on Information \& Technology, 1994, p. 5.

${ }^{5}$ Holloway, Robert Evan, Christina S. Doyle and John Lindsay. "Performance Assessment for Information Literacy," in: Instructional Interventions for Information Use: Papers of Treasure Mountain VI. p. 2.

${ }^{6}$ Ibid.

${ }^{7}$ Woolls, Blanche. "Assessment Methods: On Beyond Craver: A Project in Process," in: Instructional Interventions for Information Use: Papers of Treasure Mountain VI. p. 14-57

${ }^{8}$ Scriven, M. and R. Paul. Goals of the National Council for Excellence in Critical Thinking Instruction. Santa Rosa, CA: Foundation for Critical Thinking, 1991.

${ }^{9}$ King, A. "Inquiry as a Tool in Critical Thinking." in: Halpern, Changing College Classrooms: New Teaching and Learning Strategies for an Increasingly Complex World. San Francisco, CA: Jossey-Bass Publishers, 1994, p. 13.

${ }^{10}$ Moody, Regina B. "Consider the Source," in: Instructional Interventions for Information Use: Papers of Treasure Mountain VI. p. 115-125.

${ }^{11}$ Veyer, Bruce. Practical Strategies for the Teaching of Thinking. Boston, MA: Allyn and Bacon, 1987, p. 27.

${ }^{12}$ Quellmalz, E.S. "Needed: Better Methods for Testing Higher-Order thinking Skills," Educational Leadership, vol. 43, no. 29, October, 1985, p. 30.

${ }^{13}$ Woolls, Blanche. "Assessment Methods: On Beyond Craver: A Project in Process," in: Instructional Interventions for Information Use: Papers of Treasure Mountain VI. p. 14.

${ }^{14}$ Daniel, Eileen. "High School to University: What Skills Do Students Need?" in: Lighthall, Lynne and Ken Haycock, eds., Information Rich but Knowledge Poor? Emerging Issue for Schools and Libraries Worldwide. Seattle, WA: International Association of School Librarianship, 1997, p. 53-62

${ }^{15}$ Callison, Daniel and Carol Tilley. "The Literatus of Media and Information." in: Instructional Interventions for Information Use: Papers of Treasure Mountain VI. p. 377-379.

${ }^{16}$ Stripling, Barbara K. and Judy M. Pitts. Brainstorms and Blueprints. Englewood, CO: Libraries Unlimited, 1988. 
${ }^{17}$ Kuhlthau, Carol C. "Information Search Process: A Summary of Research and Implications for School Library Media Programs." School Library Media Quarterly, Vol. 22, no.1, Fall, 1989, p. 19-25. also:

Kuhlthau, Carol C. "The Process of Learning from Information." School Libraries Worldwide, Vol. 1, no.1, 1995, p. 1-12.

${ }^{18}$ Eisenberg, Michael B. and Robert E. Berkowitz. Information Problem-Solving: The Big Six Skills Approach to Library and Information Skulls Instruction. Norwood, NJ: Ablex, 1990. also Eisenberg, Michael B. and Robert E. Berkowitz. Curriculum Initiative: An Agenda and Strategy for Library Media Programs. Norwood, NJ: Ablex, 1990. also Eisenberg, Michael B. and Robert E. Berkowitz. Helping with Homework: A Parent's Guide to Information Problem-Solving. Syracuse, NY: ERIC Clearinghouse on Information \& Technology, 1996.

${ }^{19}$ California School Library Association. From Library Skills to Information Literacy: A Handbook for the 21st Century. 2nd edition. Castle Rock, CO: Hi Willow Research and Publishing, 1997. (The first edition of this book was published under the authorship of the California Media and Library Association in 1994)

${ }^{20}$ Pappas, Marjorie L. "Follett Information Skills Model." in: Teaching Electronic Information Skills. 3 binders: K-5; 6-8; 9-12. McHenry, IL: Follett Software Company, 1995. also Pappas, Marjorie L. and Gail A. Geitgey and Cathy A. Jefferson. Searching Electronic Sources. Worthington, OH: Linworth Publishing, 1996. also Pappas, Marjorie. Pathways to Knowledge: Follett's Information Skills Model. Kit. McHenry, IL: Follett Software Company, 1997.

${ }^{21}$ AASL \& AECT. "Information Literacy Standards for Student Learning." Hotline Connections. vol. 4, no.1, Fall, 1996. p. 2-3.

${ }^{22}$ American Association of School Librarians. Standards for School Library Programs. Chicago: American Library Association, 1960, p. 18-19.

${ }^{23}$ Kuhlthau, Carol Collier. Information Skills for an Information Society: a Review of the Research. Syracuse, NY: ERIC Clearinghouse on Information Resources, 1987.

${ }^{24}$ Doyle, Christina S. Information Literacy in an Information Society: A Concept for the Information Age. Syracuse University: ERIC Clearninghourse on Information \& Technology, 1994.

${ }^{25}$ Bruce, Christine Susan. Information Literacy: A Phenomenography. Unpublished doctoral dissertation, The University of New England (Australia), 1996.

${ }^{26}$ Zurkowski, Paul. The Information Service Environment Relationships and Priorities. Washington, DC: National Commission on Libraries and Information Science, 1974. ED 100391.

${ }^{27}$ Cooke, Michael J. "Information Skills for the Modern World: Can the School Library Cope?" in: Haycock, Ken and Blanche Woolls, eds. School Librarianship: International Issues and Perspectives. Seattle, WA: International Association of School Librarianship, 1977. (dist. LMC Source, P.O. Box 266, Castle Rock, CO 80104)

${ }^{28}$ Eleanor Howe lists other documents issued by the British Library during this period in her: Howe, Eleanor B. "Integrating Information Technology into and Across the Curriculum: A Short Course for Secondary Students." in: in: Lighthall, Lynne and Ken Haycock, eds., Information Rich but Knowledge Poor? Emerging Issue for Schools and Libraries Worldwide. Seattle, WA: International Association of School Librarianship, 1997, p. 75-86.

${ }^{29}$ Markless, S. and Lincoln. P. eds., Tools for Learning. London: British Library, 1986. also Irving, Ann. Study and Information Skills Across the Curriculum. London: Heinemann, 1985. also Carter, C. and J. Monaco. Learning Information Skills. London: British Library, 1987. 
${ }^{30}$ Hughes, Carolyn S. “Teaching Strategies for Developing Student Thinking," in: Information Literacy: Learning How to Learn. Chicago: American Library Association, 1991, p. 33-36. (also in School Library Media Quarterly, Fall, 1986 issue)

${ }^{31}$ Kulleseid, Eleanor R. "Extending the Research Base: Schema Theory, Cognitive Styles, and Types of Intelligence," in: Information Literacy: Learning How to Learn, Chicago: American Library Association, 1991, p. 41-48. (also in School Library Media Quarterly, Fall, 1986 issue)

${ }^{32}$ Mancall, J.C., Shirley Aaron and ___ Walker. "Educating students to think: The role of the School Library Media Program," School Library Media Quarterly, vol. 15, no. 1, Fall, 1986, p. 18-27.

${ }^{33}$ Hall, N. Teachers, Information and School Libraries. UNESCO, General Information Programme, Paris. ED $275342,1986$.

${ }^{34}$ Kuhlthau, Carol Collier. Information Skills for an Information Society: a Review of the Research. Syracuse, NY: ERIC Clearinghouse on Information Resources, 1987.

${ }^{35}$ Washington Library Media Association. Information Skills Curriculum Guide: Process, Scope and Sequence . Olympia, WA: Washington State Department of Education, 1997. ED 288554.

${ }^{36}$ American Association of School Librarians and Association for Educational Communications and Technology. Information Power. Chicago: American Library Association, 1988.

${ }^{37}$ Craver, Kathleen W. "Critical Thinking: Implications for Research," in: Information Literacy: Learning How to Learn. Chicago: American Library Association, 1991, p. 13-18. (also in School Library Media Quarterly, Fall, 1989 issue)

${ }^{38}$ Kuhlthau, Carol C. "Information Search Process: A Summary of Research and Implications for School Library Media Programs," in: Information Literacy: Learning How to Learn. Chicago: American Library Association, 1991, p. 19-25. (also in School Library Media Quarterly, Fall, 1989 issue)

${ }^{39}$ American Library Association Presidential Committee on Information Literacy. Final Report. Chicago: ALA, 1989. (available on the AASL Electronic Library), also in: Information Literacy: Learning How to Learn, Chicago: American Library Association, 1991.

${ }^{40}$ Turner, Philip M. "Research Reviews from the Treasure Mountain Research Retreat," in: Smith, Jane Bandy. School Library Media Annual, 1990. Englewood, CO: Libraries Unlimited, p. 139-53.

${ }^{41}$ Wisconsin Educational Media Association and the American Association of School Librarians. "Information Literacy: A Position Paper on Information Problem Solving, 1993.”

${ }^{42}$ Colorado Department of Education. "Model Information Literacy Guidelines." Denver, CO: State Library and Adult Education Office. Unpublished Paper, 1994. (available on the AASL Electronic Library)

${ }^{43}$ Doyle, Christina S. Information Literacy in an Information Society: A Concept for the Information Age. Syracuse, NY: ERIC Clearinghouse on Information \& Technology, 1994.

${ }^{44}$ Brock, Kathy Thomas. "Developing Information Literacy Through the Information Intermediary Process: A Model for Teacher-Librarians and Others." Emergency Librarian, vol. 22, no. 1, September-October, 1994, p. 16-20.

${ }^{45}$ O'Connell, Judy and James Henri. "Information Literacy: Teacher's Perspectives of the Information Process," in: Lighthall, Lynne and Ken Haycock, eds., Information Rich but Knowledge Poor? Emerging Issue for Schools and Libraries Worldwide. Seattle, WA: International Association of School Librarianship, 1997, p. 125-36. 
${ }^{46}$ Wilson, Kay. "Information Skills: The Reflections and Perceptions of Student Teachers and Related Professionals," in: Lighthall, Lynne and Ken Haycock, eds., Information Rich but Knowledge Poor? Emerging Issue for Schools and Libraries Worldwide. Seattle, WA: International Association of School Librarianship, 1997, p. 6374.

${ }^{47}$ Loertscher, David V. “All that Glitters May Not Be Gold" Emergency Librarian. November/December, 1996, p. 21-25.

${ }^{48}$ Reeves, Wayne. Cognition and Complexity. Shoestring Press, 1996. also Loertscher, David V. and Wayne Reeves. "Deepening Our Knowledge of Young People in the Expanding Information Environment: A Model for Field Research.” In: Instructional Interventions for Information Use: Papers of Treasure Mountain VI. p. 361-76.

${ }^{49}$ von Wodtke, Mark. Mind over Media: Creative Thinking Skills for Electronic Media. New York: McGrawHill, 1993. also: von Wodtke, Mark. "Thinking Skills for the Electronic Information Age: Applying Mental Capacity," in: Kuhlthau, Carol Collier, M. Elspecth Goodin and Mary Jane Mcnally, eds. School Library Media Annual 1994. Englewood, CO: Libraries Unlimited, 1994, p. 54-62.

${ }^{50}$ McKenzie, Jamie. "Making WEB Meaning.” Educational Leadership. vol. 54, no. 3, 1996, p. 30-32. also McKenzie, Jamie. "Planning a Voyage into Cyberspace." Technology Connections, vol. 2, no.2, 1995, p. 9-11.

${ }^{51}$ Fitzgerald, Mary Ann. "Misinformation on the Internet: Applying Evaluation Skills to Online Information." Emergency Librarian, vol. 24, no. 3, January-February, 1997, p. 9-14.

${ }^{52}$ Eisenberg, Michael B. and Doug Johnson. "Computer Skills for Information Problem-Solving: Learning and Teaching Technology in Context" ERIC Digest EDO-IR-96-04, Syracuse, NY: Clearinghouse on Information \& Technology, March, 1996. See also their article: "Computer Literacy and Information Literacy: A Natural Combination,” Emergency Librarian, vol.23, no. 5, May-June, 1996, p. 12-16.

${ }^{53}$ Penrod, J.I. and J. V. Douglas, "Information Technology Literacy: A Definition," in: Kent, Allen, ed. Encyclopedia of Library and Information Science, vol. 40, p. 76-107.

${ }^{54}$ Considine, David M. and Gail E. Haley. Visual Messages: Integrating Imagery into Instruction. Englewood, CO: Teacher Ideas Press, 1992.

${ }^{55}$ Summers, Sue Lockwood. Media Alert!: 200 Activities to Create Media-Savvy Kids. Castle Rock, CO: Hi Willow Research and Publishing, 1997.

${ }^{56}$ Pappas, Marjorie L. and Ann E. Tepe: "Media, Visual, Technology and Information: A Synthesis of Literacies," in: Instructional Interventions for Information Use: Papers of Treasure Mountain VI. p. 328-347.

${ }^{57}$ Ennis, R.H. "A Taxonomy of Critical Thinking Dispositions and Abilities.” in: J.B. Baron and R.J. Sternberg, eds. Teaching Thinking Skills: Theory and Practice. New York: W. H. Freeman and Company, 1987, p. 12-15.

${ }^{58}$ Center for Critical Thinking. "Strategy List: 35 Dimension of Critical Thought (Formally Named)" in: Critical Thinking Primary \& Secondary Information: Library. URL: www.sonoma.edu/cthink/K12/default.html

${ }^{59}$ The Secretary's Commission on Achieving Necessary Skills (SCANS) Report. Washington, DC: U.S. Department of Labor, 1992. Skills related to information literacy in this report summarized in: Holloway, Robert Evan and Christina S. Doyle and John Lindsay. "Performance Assessment for Information Literacy." in: Instructional Interventions for Information Use: Papers of Treasure Mountain VI. p. 1-12.

${ }^{60}$ Eisenberg, Michael B. and Robert E. Berkowitz. Helping with Homework: A Parent's Guide to Information Problem-Solving. Syracuse, NY: ERIC Clearinghouse on Information \& Technology, 1996. 
${ }^{61}$ Thompson, Loren J. Habits of Mind. University Press of America, 1995.

${ }^{62}$ Macrorie, Ken. The I-Search Paper. Portsmouth, NH: Heinemann, 1988.

${ }^{63}$ Dalbotten, Mary S. "Inquiry in the National Content Standards." in: Instructional Interventions for Information Use: Papers of Treasure Mountain VI. p. 246-304.

${ }^{64}$ Music Educators National Conference. National Standards for Arts Education. Reston, VA: The Conference, 1994.

${ }^{65}$ Center for Civic Education. National Standards for Civics and Government. Calabasas, CA: The Center, 1994.

${ }^{66}$ National Council of Teachers of English. Standards for the English Language Arts. Urbana, IL: The Council, 1996.

${ }^{67}$ Standards for Foreign Language Learning: Preparing for the 21st Century. Lawrence, KS: Allen Press, 1996.

${ }^{68}$ Bednarz, S. W. and others. Geography for Life: National Geography Standards. Washington, DC: Department of Education, National Endowment for the Humanities, and the National Geographic Society, 1994.

${ }^{69}$ Joint Committee on National Health Education Standards. National Health Education Standards. Washington, DC: American Cancer Society, 1995.

${ }^{70}$ National Center for History in the Schools. National Standards for History. Los Angeles, CA: The Center, 1996.

${ }^{71}$ National Council of Teachers of Mathematics. Curriculum and Evaluation Standards for School Mathematics. Reston, VA: The Council, 1989.

${ }^{72}$ National Association for Sport \& Physical Education. Moving into the Future: National Physical Education Standards: A Guide to Content and Assessment. St. Louis, MO: Mosby, 1995.

${ }^{73}$ National Science Education Standards. Washington, CD: National Academy Press, 1996.

${ }^{74}$ National Council of the Social Studies. Expectations of Excellence: Curriculum Standards for Social Studies. Washington, DC: The Council, 1994.

${ }^{75}$ Hutchinson, J. and J. Karsnitz. Design and Problem Solving in Technology. Albany, NY: Delmar, 1994. also: Todd, R.D. and others. Introduction to Design and Technology. Cincinnati, OH: Thomson Learning Tools, 1995.

${ }^{76}$ Van Deusen, Jean Donham and Julie I. Tallman. "The Impact of Scheduling on Curriculum Consultation and Information Skills Instruction, Part One: The 1993-94 AASL/Highsmith Research Award Study," School Library Media Quarterly, vol. 23, no. 1, Fall, 1994, p. 17-25.

${ }^{77}$ Kuhlthau, Carol C. "Implementing a Process Approach to Information Skills: A Study Identifying Indicators of Success in Library Media Programs," School Library Media Quarterly, vol. 22, no. 1, Fall, 1993, p. 11-18. (quote from p. 18)

${ }^{78}$ Eisenberg, Michael B. and Robert E. Berkowitz. Information Problem-Solving: The Big Six Skills Approach to Library and Information Skulls Instruction. Norwood, NJ: Ablex, 1990. also Eisenberg, Michael B. and Robert E. Berkowitz. Curriculum Initiative: An Agenda and Strategy for Library Media Programs. Norwood, NJ: Ablex, 1990. also Eisenberg, Michael B. and Robert E. Berkowitz. Helping with Homework: A Parent's Guide to Information Problem-Solving. Syracuse, NY: ERIC Clearinghouse on Information \& Technology, 1996. 
${ }^{79}$ Eisenberg, Michael B. Teaching Information Skills: The Big Six Model Video. Castle Rock, CO: Hi Willow Research and Publishing (Distributed by LMC Source), 1993.

${ }^{80}$ The listserv title is: BIGSIX@LISTSERV.SYR.EDU

${ }^{81}$ Stripling, Barbara K. and Judy M. Pitts. Brainstorms and Blueprints. Englewood, CO: Libraries Unlimited, 1988.

${ }^{82}$ California School Library Association. From Library Skills to Information Literacy: A Handbook for the 21st Century. 2nd edition. Castle Rock, CO: Hi Willow Research and Publishing, 1997. (The first edition of this book was published under the authorship of the California Media and Library Association in 1994)

${ }^{83}$ Information Literacy: Learning How to Learn: A Collection of Articles from School Library Media Quarterly, Journal of the American Association of School Librarians. Chicago: American Library Association, 1991.

${ }^{84}$ a summary of the work in text structure with an attendant bibliography into the literature is: Moody, Regina. "Consider the Source." in: Instructional Interventions for Information Use: Papers of Treasure Mountain VI. p. $115-25$.

${ }^{85}$ Stripling, Barbara K. "Learning-Centered Libraries: Implications from Research," School Library Media Quarterly, vol. 23, no. 3, Spring, 1995, p. 163-70.

${ }^{86}$ summarized in Gordon, Mark W. "Location vs. Reflection: School Librarians, Student Thinking and the World Wide Web." in: Instructional Interventions for Information Use: Papers of Treasure Mountain VI. p. 193-99.

${ }^{87}$ Tastad, Shirley A. and Norma Decker Collins. "Teaching the Information Skills Process and the Writing Process: Bridging the Gap," School Library Media Quarterly, Vol. 25, No. 3, Spring, 1997, p. 167-69.

${ }^{88}$ Gross, Melissa. "Pilot Study on the Prevalence of Imposed Queries in a School Library Media Center," School Library Media Quarterly, Vol. 35, no.3: Spring, 1977, p. 157-66.

${ }^{89}$ Pitts, Judy M. edited by John H. McGregor and Barbara K. Stripling. "Mental Models of Information: The 199394 AASL/Highsmith Research Award Study," School Library Media Quarterly, vol. 23, no. 3, Spring, 1995, p. 177-84.

${ }^{90}$ Ibid, p. 181.

${ }^{91}$ Nahl, Diane and Violet H. Harada. "Composing Boolean Search Statements: Self-Confidence, Concept Analysis, Search Logic, and Errors," School Library Media Quarterly, vol. 24, no. 4, Summer, 1996, p. 199-206.

${ }^{92}$ Walter, Virginia A., Christine L. Borgman, and Sandra G. Hirsh. "The Science Library Catalog: A Springboard for Information Literacy," In: “Current Research" column, School Library Media Quarterly, vol. 24, no. 2, Winter, 1996, p. 105-110.

${ }^{93}$ Solomon, Paul. "Children, Technology, and Instruction: A Case Study of Elementary School Children Using an Online Public Access Catalog (OPAC)," in: "Current Research" column, School Library Media Quarterly, vol. 23, no. 1, Fall, 1994, p. 43-53.

${ }^{94}$ Kafai, Yasmin and Marcia J. Bates. "Internet Web-Searching Instruction in the Elementary Classroom: Building a Foundation for Information Literacy," School Library Media Quarterly, vol. 25, no. 2, Winter, 1997, p. 103-11.

${ }^{95}$ McGregor, Joy and Denise Streitenberger. "Do Scribes Learn? Copying and Information Use," in: Instructional Interventions for Information Use: Papers of Treasure Mountain VI. p. 307-27. 
${ }^{96}$ Havener, W. Michael and Kathy Latrobe. "Understanding the Information-Seeking Behavior of High School Honors Students: Insights from Phychosocial Theories," in: Instructional Interventions for Information Use: Papers of Treasure Mountain VI. p. 84-99.

${ }^{97}$ Small, Ruth V. "Motivational Aspects of Library and Information Sklills Instruction: The Role of the Library Media Specialist," in: Instructional Interventions for Information Use: Papers of Treasure Mountain VI. p. 20122.

${ }^{98}$ Friel, Linda de Lyon. "Interventions That Facilitate the Information Research Process with Low-Achieving Freshmen Using Kuhlthau's Six-Stage Model." in: Instructional Interventions for Information Use: Papers of Treasure Mountain VI. p. 126-92.

${ }^{99}$ McGregor, Joy H. "Cognitive Processes and the Use of Information: a Qualitative Study of Higher-OrderThinking Skills Used in the Research Process by Students in a Gifted Program," in: Kuhlthau, Carol Collier, M. Elspecth Goodin and Mary Jane Mcnally, eds. School Library Media Annual 1994. Englewood, CO: Libraries Unlimited, 1994, p. 124-33.

${ }^{100}$ Garland, Kathleen. "The Information Search Process: A Study of Elements Associated with Meaningful research Tasks," in: Morris, Betty J., Judith L. McQuiston and Cecile L. Saretsky. School Library Media Annual 1995. Englewood, CO: Libraries Unlimited, 1995, p. 171-83.

${ }^{101}$ Todd, Ross J. "Meeting Drug Information Needs of Adolescents," in: Lighthall, Lynne and Ken Haycock, eds., Information Rich but Knowledge Poor? Emerging Issue for Schools and Libraries Worldwide. Seattle, WA: International Association of School Librarianship, 1997, p. 97-108.

${ }^{102}$ Walster, Dian. “Bilingual Students and Information Literacy Skills: An Urban Middle School Tale,” in: Instructional Interventions for Information Use: Papers of Treasure Mountain VI. p. 348-60.

${ }^{103}$ Todd, Ross J. "Integrated Information Skills Instruction: Does It Make a Difference?" in: "Current Research," School Library Media Quarterly, vol. 23, no. 2, Winter, 1995, p. 133-39. Other studies of the impact of information literacy are included in the research column within the pages cited.

${ }^{104}$ Kuhlthau, Carol Collier, M. Elspeth Goodin and Mary Jane McNally. Assessment and the School Library Media Center. Englewood, CO: Libraries Unlimited, 1994.

${ }^{105}$ Madaus, George F. and Ann G. A. Tan. "The Growth of Assessment," in: Kuhlthau, Carol Collier, M. Elspeth Goodin and Mary Jane McNally. Assessment and the School Library Media Center. Englewood, CO: Libraries Unlimited, 1994, p. 1-24

${ }^{106}$ Neuman, Delia. "Alternative Assessment: Promises and Pitfalls," in: Kuhlthau, Carol Collier, M. Elspeth Goodin and Mary Jane McNally. Assessment and the School Library Media Center. Englewood, CO: Libraries Unlimited, 1994, p. 67-75.

${ }^{107}$ Jackson, Mary M. "Library Information Skills and Standardized Achievement Tests," in: Kuhlthau, Carol Collier, M. Elspeth Goodin and Mary Jane McNally. Assessment and the School Library Media Center. Englewood, CO: Libraries Unlimited, 1994, p. 25-32.

${ }^{108}$ Colorado State Library and Adult Education Office and Colorado Educational Media Association. "Rubrics for the Assessment of Information Literacy: A Companion to the Information Literacy Rubrics for School Library Media Specialists," In: California School Library Association: From Library Skills to Information Literacy: A Handbook for the 21st Century, 2nd. ed. Castle Rock, CO: Hi Willow Research \& Publishing, 1997, p. 131-42. 
${ }^{109}$ Grover, Robert and Jacqueline McMahon Lakin and Jane Dickerson. “An Interdisciplinary Model for Assessing Learning," in: Lighthall, Lynne and Ken Haycock, eds., Information Rich but Knowledge Poor? Emerging Issue for Schools and Libraries Worldwide. Seattle, WA: International Association of School Librarianship, 1997, p. 87-96.

${ }^{110}$ Norris, S. P. and R. H. Ennis. Evaluating Critical Thinking. Pacific Grove, CA: Midwest Publications Critical Thinking Press, 1989.

${ }^{111}$ Resnick, L.B. Education and Learning to Think. Washington, D.C.: National Academy Press, 1987, p. 37.

${ }^{112}$ Woolls, Blanche. “Assessment Methods: On Beyond Craver: A Project in Process,” in: Instructional Interventions for Information Use: Papers of Treasure Mountain VI. p. 14-57

${ }^{113}$ Paul, R. and G. M. Nosich,” A Model for the National Assessment of Higher Order Thinking," ED 3533296. Santa Rosa, CA: Foundation for Critical Thinking, 1992.

${ }^{114}$ Brookfield, S. D. Developing Critical Thinkers: Challenging Adults to Explore Alternative Ways of Thinking and Acting. San Francisco: Jossey-Bass, 1989.

${ }^{115}$ Baron, J. B. "Evaluating Thinking Skills in the Classroom,” in: Baron, J. B., and R. J. Sternberg, eds. Teaching Thinking Skills: Theory and Practice. New York: W.H. Freeman and Company, 1987.

${ }^{116}$ Halpren, D. F. “Assessing the Effectiveness of Critical Thinking Instruction," JGE: The Journal of General Education, vol. 42, p. 238-54, 1993. 